\title{
Dual plate osteosynthesis in bicondylar tibial plateau fractures-case series
}

\section{Shreekantha Koteshwara Surendra Rao, Mahammad Aseem Mahammadgous Mulla*, Deepak Malik, Mohammed Usman}

Department of Orthopaedics, Sapthagiri Institute of Medical Sciences \& Research Centre, Bangalore, Karnataka, India

Received: 28 April 2021

Accepted: 29 May 2021

\section{*Correspondence:}

Dr. Mahammad Aseem Mahammadgous Mulla,

E-mail: simmb4u@gmail.com

Copyright: (C) the author(s), publisher and licensee Medip Academy. This is an open-access article distributed under the terms of the Creative Commons Attribution Non-Commercial License, which permits unrestricted non-commercial use, distribution, and reproduction in any medium, provided the original work is properly cited.

\begin{abstract}
Tibial plateau fractures accounts for about $1 \%$ of injuries. Various mechanisms have been described, resulting in milder form to serious injuries depending upon force of impact. High velocity injuries resulted from valgus or varus impacted forces combined with axial loading such as in Schatzker type 6. The ideal method of treatment for these fractures is always a matter of debate. As all intra-articular fractures necessitate anatomic reduction of the articular surface, restoration of axial alignment, and stable fixation, which can be achieved very well by open reduction and internal fixation (ORIF) with dual plating. To study the functional and radiological outcome of Tibial plateau fractures treated surgically with dual plate osteosynthesis. 15 patients in the age group 18-60 were included. Rasmussens criteria was used to assess the functional and radiological outcomes with follow up period of 1 year prospectively. The outcome assessment using Rasmussens score concluded good results. The average duration for union was 6 months. ROM achieved in these patients were to be at least 124 degrees. The infection rate in this study was accounted as $13.3 \%$. Open reduction and internal fixation of tibial plateau fractures, by dual plating has good functional and radiological outcome. This is an effective method of treatment even with moderate soft tissue injury if meticulous surgical technique, appropriate soft tissue handling and adequate healing period given. All these have shown to decrease the postoperative complications such as infection.
\end{abstract}

Keywords: Tibial plateau fractures, Schatzker type VI, Dual plate osteosynthesis, Rasmussens score

\section{INTRODUCTION}

Tibial plateau fractures have bimodal distribution, with high-energy trauma in younger patients and low-energy falls in elderly due to osteoporotic bone. The incidence is 10.3 per 100,000 population annually. ${ }^{1}$ High-energy trauma associated with soft-tissue injury, comminution and complex fracture geometry which further complicates the management of such fractures. ${ }^{1}$

The ideal fixation method still remains controversial. With improvement in the current concepts and approaches allows better understanding of fracture geometry and fixation of posteromedial fragment, which is associated in up to $33 \%$ of cases. ${ }^{2}$ The goals in treating fractures of the tibial plateau are to restore the joint congruity, to correct mechanical alignment of the limb, optimal healing of bone and soft tissues, to allow pain-free full range of motion of the knee.

The main objective of the study was to assess the anatomical reduction of articular surface by open reduction and Internal fixation with fracture specific approach. To assess the radiological union and the clinical outcomes associated with this treatment modality in terms of knee range of movements, pain relief, return to normal activities including occupation using modified Rasmussen criteria. 


\section{CASE SERIES}

This is a case series of 15 consecutive tibial plateau fractures. We reviewed all patients with tibial plateau fractures at our tertiary centre between August 2019 to March 2020. Inclusion criteria consisted of patients above 18 years and below 60 years, closed tibial plateau fractures with a minimum of the 12 months follow-up. Demographics and mode of injury described in the Table 1 and 2.

Preoperative radiographs were reviewed and classified according to Schatzker classification system. During the period between August 2019-March 2020, 15 patients with tibial plateau fracture were treated by dual plate osteosynthesis and followed up to evaluate the results. All the required data was obtained from the patients during their stay in the hospital or during follow up and recorded in the proforma.

All cases of type VI Schatzker tibial plateau fractures on presentation to the emergency department were treated by initial resuscitation and temporary stabilization of fracture using above knee slab and later treated by definitive fixation.

$\mathrm{X}$ rays were taken in the antero-posterior and lateral views and noted for confirming tibial plateau fracture pattern, amount of articular surface widening, depression and comminution.

CT scan with 3D reconstruction was done to know about the fracture lines and degree of fragment displacement and for preoperative planning. The choice of approach and placement of plates and screws is decided according to the CT scan. Once resolution of the edema and the fracture blisters if any and appearance of skin wrinkles, the patient was planned for surgery.

The patient was placed in supine position with a sand bag under ipsilateral hip for anterolateral approach. We usually fix medial tibial condyle first. If medial condyle is comminuted, we fix lateral condyle to achieve length. Lobenhoffer approach used for the post-eromedial exposure.

Through posteromedial approach to proximal tibia, approximately $6 \mathrm{~cm}$ incision over posteromedial border of proximal tibia. The long saphenous vein and saphenous nerve identified and preserved. Pes anserinus expansions identified. Tibia approached after incising pes anserinus longitudinally along the line of incision. The gastrocnemius was gently freed from posteromedial surface using blunt dissection. The fracture fragments visualized, reduced under $\mathrm{c}$ arm guidance. In case of articular depression, a bone punch was used to elevate the depressed fragment and the void was filled with bone graft. The reduced fragments were fixed with proximal tibia posterior medial locking plate.
The lateral condyle fracture approached antero-laterally. Incision was made starting $5 \mathrm{~cm}$ proximal to joint line curving the incision anteriorly over Gerdy's tubercle and extend it distally $1 \mathrm{~cm}$ lateral to anterior border of tibia. Tibialis anterior was elevated by blunt dissection. Under C arm guidance, fracture reduced and fixed with proximal Tibia Lateral Locking Plate. If depression was present, bone grafting was done if necessary.

The articular reduction of depressed fragment is elevated with compacted cancellous bone beneath it and the resultant metaphyseal void is filled with autogenous cancellous or synthetic bone graft. Image intensifier is used to position the plate below the level of the joint line and the plate is then fixed with screws.

Post-operatively, knee is immobilized in long knee brace. The data including postoperative rehabilitation, antibiotics and development of any complications are noted. Postoperative radiographs reviewed to assess the articular reduction, metaphyseo-diaphyseal reduction, and alignment. Non-weight-bearing mobilization, ROM and quadriceps exercises are started on the $1^{\text {st }}$ post-operative day (POD). wound inspection is done on $2^{\text {nd }}$ and $5^{\text {th }}$ postoperative day. Suture removal is done on $14^{\text {th }}$ postoperative day.

Patients were reviewed in outpatient basis at two weeks for suture removal, four weeks, six months and twelve months for clinical and radiological assessment. Toe touch weight bearing was started after four weeks. Full weight bearing was allowed after the radiological evidence of the bony union.

At each follow up, surgical site examined for wound dehiscence, radiological evaluation using standard AP lateral knee projections was done for assessing fracture union, loss of reduction if any and implant related complications. Knee function was assessed and scored according to modified Rasmussen criteria.

Table 1: Sex distribution.

\begin{tabular}{|ll|l|}
\hline Sex of patient & No. of patients & $\begin{array}{l}\text { Percentage } \\
(\%)\end{array}$ \\
\hline Male & 10 & 66.7 \\
\hline Female & 5 & 33.3 \\
\hline Total & 15 & 100 \\
\hline
\end{tabular}

Table 2: Mode of injury.

\begin{tabular}{|lll|}
\hline Mode of injury & & \\
\hline Age (Years) & RTA & Fall from height \\
\hline $\mathbf{2 1 - 3 0}$ & 3 & 1 \\
\hline $\mathbf{3 1 - 4 0}$ & 4 & 0 \\
\hline $\mathbf{4 1 - 5 0}$ & 4 & 0 \\
\hline $\mathbf{5 1 - 6 0}$ & 1 & 2 \\
\hline Total & 12 & 3 \\
\hline Percentage (\%) & 80 & 20 \\
\hline
\end{tabular}


Table 3: Complications.

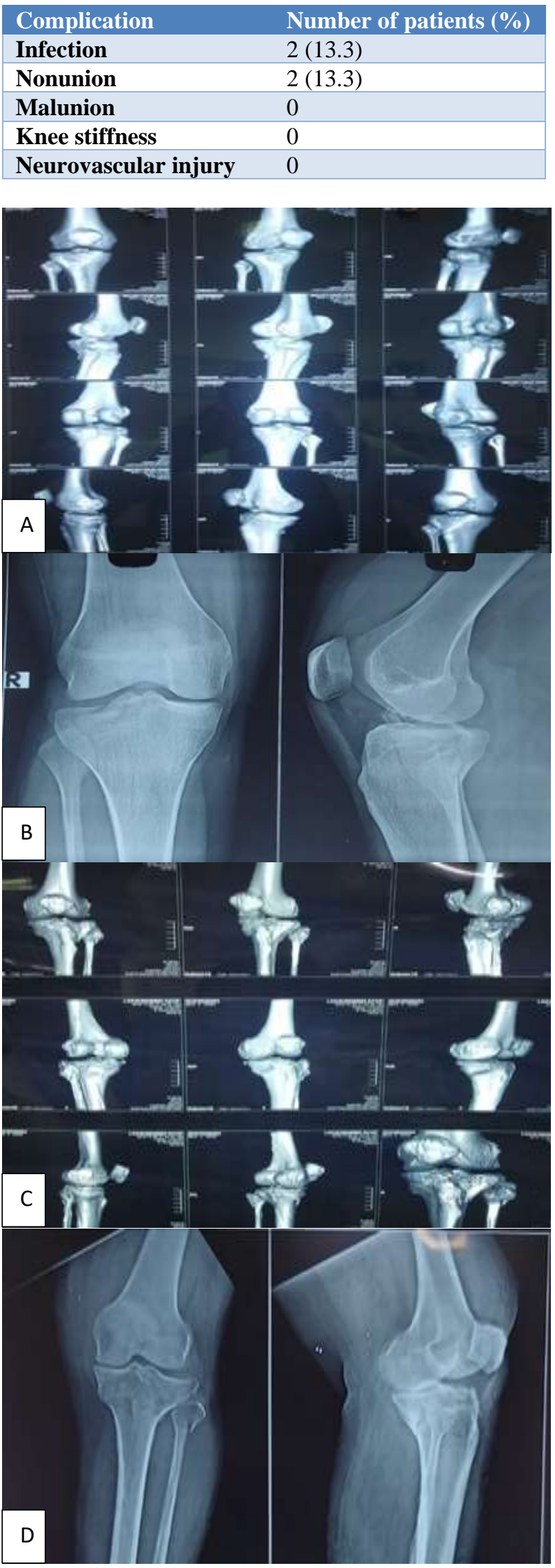

Figures 1 (A-D): Pre-op radiographs of patients.

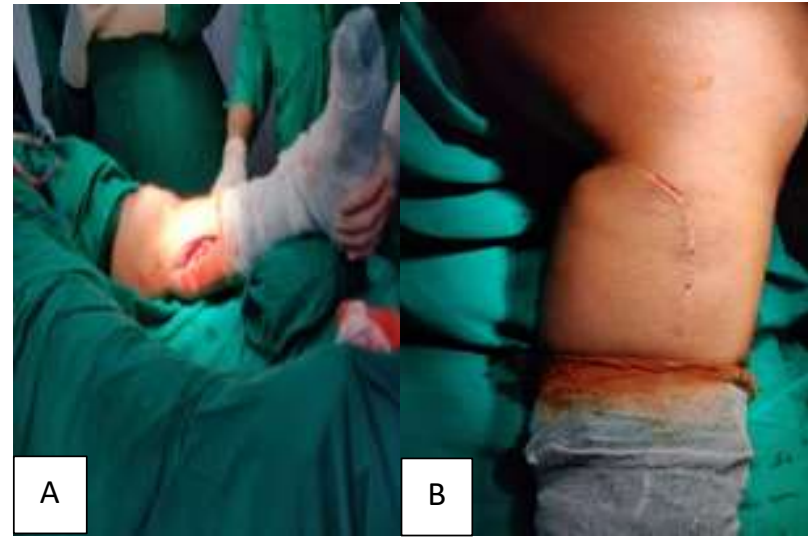

Figure 2 (A and B): Intra-op preparation and incision.
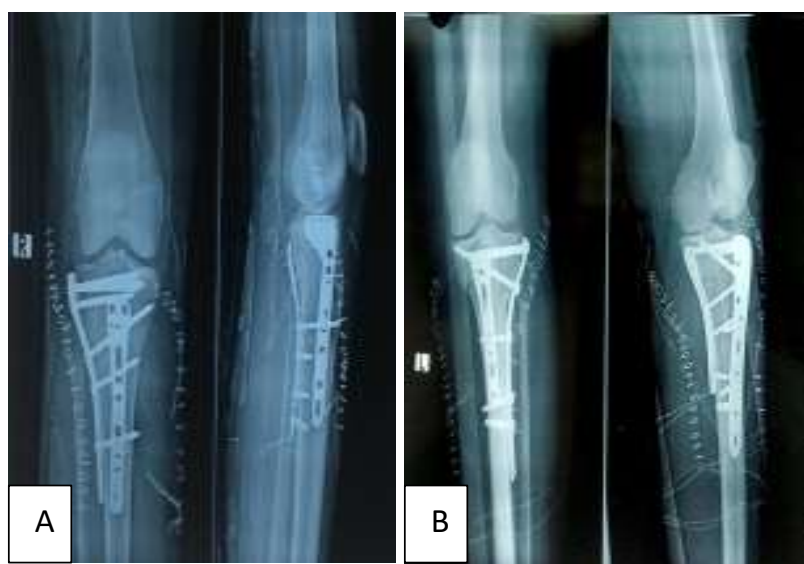

Figure 3 (A and B): Post-op radiographs.

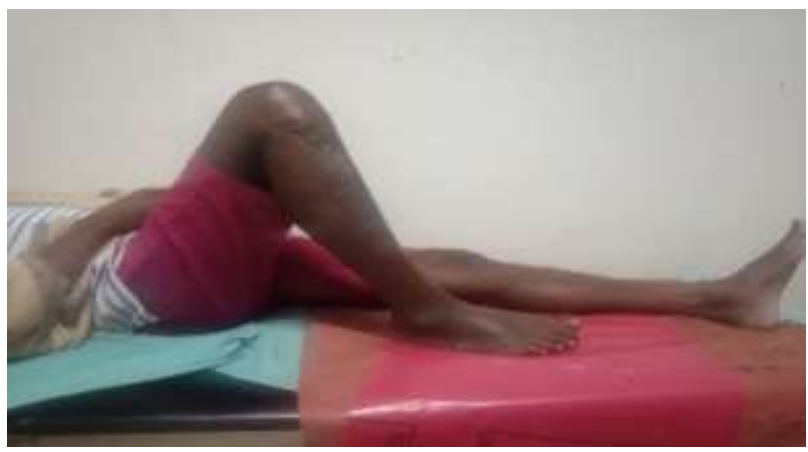

Figure 4: Post-op knee ROM.

\section{DISCUSSION}

This study included 15 patients with tibial plateau fractures. Most of the patients in our study are males in the age group of 30-40 years. At the final follow-up, the mean range of motion of the knee joint was 124 degrees, as summarized in Table 4. Bony union occurred by 6 months after surgery in most of the cases, as summarized in Table 5. There were two cases of delayed wound healing as a postoperative complication, it was determined that an additional operation was not required. The same cases have poor scores in modified Rasmussen functional and radiological scoring system. 
Table 4: Rasmussen score for clinical assessment.

\begin{tabular}{|c|c|c|c|c|c|c|}
\hline $\begin{array}{l}\text { Patient } \\
\text { no. }\end{array}$ & $\begin{array}{l}\text { Age/sex } \\
\text { (Years) }\end{array}$ & $\begin{array}{l}\text { Mechanism of } \\
\text { injury }\end{array}$ & $\begin{array}{l}\text { Rasmussen functional } \\
\text { score } 1 \text { month }\end{array}$ & $\begin{array}{l}\text { Rasmussen functional score } 6 \\
\text { months }\end{array}$ & $\begin{array}{l}\text { Rasmussen functional } \\
\text { score } 12 \text { months }\end{array}$ & $\begin{array}{l}\text { Functional results } 1 \\
\text { year }\end{array}$ \\
\hline 1 & $23 / \mathrm{m}$ & RTA & 25 & 26 & 26 & Good \\
\hline 2 & $42 / f$ & RTA & 21 & 25 & 27 & Good \\
\hline 3 & $56 / \mathrm{m}$ & Fall from height & 20 & 18 & 18 & Poor \\
\hline 4 & $28 / \mathrm{m}$ & RTA & 27 & 28 & 28 & Excellent \\
\hline 5 & $32 / \mathrm{m}$ & RTA & 28 & 29 & 30 & Excellent \\
\hline 6 & $45 / f$ & RTA & 25 & 25 & 26 & Good \\
\hline 7 & $51 / \mathrm{m}$ & RTA & 22 & 24 & 26 & Good \\
\hline 8 & $21 / \mathrm{m}$ & Fall from height & 24 & 27 & 27 & Good \\
\hline 9 & $39 / f$ & RTA & 26 & 26 & 26 & Good \\
\hline 10 & $46 / \mathrm{m}$ & RTA & 26 & 27 & 27 & Good \\
\hline 11 & $33 / f$ & RTA & 25 & 28 & 29 & Excellent \\
\hline 12 & $37 / \mathrm{m}$ & RTA & 24 & 25 & 26 & Good \\
\hline 13 & $54 / \mathrm{m}$ & Fall from height & 20 & 19 & 19 & Poor \\
\hline 14 & $33 / \mathrm{m}$ & RTA & 24 & 28 & 29 & Excellent \\
\hline 15 & $40 / f$ & RTA & 24 & 26 & 27 & Good \\
\hline
\end{tabular}

Table 5: Rasmussen score for radiological assessment.

\begin{tabular}{|c|c|c|c|c|c|c|c|c|c|}
\hline $\begin{array}{l}\text { Patient } \\
\text { no. }\end{array}$ & $\begin{array}{l}\text { Age/sex } \\
\text { (Years) }\end{array}$ & $\begin{array}{l}\text { Mechanism of } \\
\text { injury }\end{array}$ & $\begin{array}{l}\text { Rasmussen } \\
\text { radiological score } \\
1 \text { month }\end{array}$ & $\begin{array}{l}\text { Rasmussen } \\
\text { radiological } \\
\text { score } 6 \text { months }\end{array}$ & $\begin{array}{l}\text { Rasmussen } \\
\text { radiological score } \\
12 \text { months }\end{array}$ & $\begin{array}{l}\text { Radiological } \\
\text { results }\end{array}$ & Complications & ROM & $\begin{array}{l}\text { Radiological } \\
\text { union }\end{array}$ \\
\hline 1 & $23 / \mathrm{m}$ & RTA & 8 & 8 & 9 & Excellent & None & $0-130$ & United \\
\hline 2 & $42 / f$ & RTA & 7 & 8 & 9 & Excellent & None & $0-120$ & United \\
\hline 3 & $56 / \mathrm{m}$ & Fall from height & 3 & 3 & 4 & Poor & Infection & $10-80$ & United \\
\hline 4 & $28 / \mathrm{m}$ & RTA & 9 & 9 & 9 & Excellent & None & $0-140$ & United \\
\hline 5 & $32 / \mathrm{m}$ & RTA & 10 & 10 & 10 & Excellent & None & $0-140$ & United \\
\hline 6 & $45 / f$ & RTA & 7 & 8 & 9 & Excellent & None & $0-120$ & United \\
\hline 7 & $51 / \mathrm{m}$ & RTA & 7 & 8 & 9 & Excellent & None & $0-130$ & United \\
\hline 8 & $21 / \mathrm{m}$ & Fall from height & 8 & 8 & 9 & Excellent & None & $0-135$ & United \\
\hline 9 & $39 / f$ & RTA & 7 & 8 & 8 & Good & None & $0-120$ & United \\
\hline 10 & $46 / \mathrm{m}$ & RTA & 8 & 8 & 9 & Excellent & None & $0-125$ & United \\
\hline 11 & $33 / f$ & RTA & 10 & 10 & 10 & Excellent & None & $0-145$ & United \\
\hline 12 & $37 / \mathrm{m}$ & RTA & 9 & 9 & 9 & Excellent & None & $0-130$ & United \\
\hline 13 & $54 / \mathrm{m}$ & Fall from height & 4 & 4 & 4 & Poor & Infection & $10-70$ & United \\
\hline 14 & $33 / \mathrm{m}$ & RTA & 9 & 9 & 10 & Excellent & None & $0-145$ & United \\
\hline 15 & $40 / f$ & RTA & 8 & 8 & 9 & Excellent & None & $0-130$ & United \\
\hline
\end{tabular}


The most important finding of the current study was that dual plating of type VI tibial plateau fractures was associated with an overall $86.6 \%$ of satisfactory or anatomic reduction.

The management of tibial plateau fracture is challenging, considering soft-tissue complications, fracture comminution and morphology, and delayed complications such as varus collapse, stiffness, and arthritis. ${ }^{3,4}$ Complications are tabulated in Table 3. The goal of anatomic reduction and stable fixation can be achieved with dual plating but associated complications include delay in soft-tissue healing and implant failure. With better understanding of fracture morphologies such as coronal split and posteromedial fragment, most of the surgeons have employed dual plating in these fractures to avoid secondary loss of alignment and reduction.

Single plating for these fractures has associated with postoperative malreduction rate of $15-23 \%$, which will lead to long-term disability. Biomechanical cadaveric studies have demonstrated that dual plate fixation of these fractures allows less subsidence and loss of alignment as compared to single plate fixation. Presence of posteromedial fragment in $33 \%$ of these fractures based on CT scan requires posteromedial buttressing, hence dual plating is recommended. Various studies have suggested that single midline incision has high complication rates in the form of wound healing and sepsis. This led to development of two-incision approach which allows for addressing the posteromedial and posterolateral fracture precisely and minimizing the wound complication rate..$^{5-7}$

Dual plate fixation using locking or buttress plate through two-incision approach allows for anatomic joint reduction, adequate fixation, maintenance of alignment, and early rehabilitation to achieve better functional outcome.

The advantages of dual plating over other types of fixations include-Coronal split of the medial condyle can be fixed separately with post-eriomedial plate, better reconstruction of articular surfaces, better distribution of forces along the axis of the bone, better load sharing capability with dual plates compared to single lateral plate alone. Dual plates resist displacement, medial condyle collapse and allow early mobilization of the knee joint. ${ }^{3-6}$

Purpose of this prospective study was to evaluate the clinical and radiological outcomes of dual plating technique for treating type VI tibial plateau fracture. Association for osteosynthesis/association for the study of internal fixation has indicated dual plating for fixation of bicondylar tibial plateau fracture dislocations. ${ }^{8-11}$ We have utilized the same principles in our study and found that the functional outcome is good to excellent in most of the cases.

The routinely applied approach in most of these cases is combination of anterolateral and posteromedial which allows sufficient skin bridge to allow wound healing and prevent wound complications.

In our experience, adequate preoperative planning along with meticulous surgical technique and aggressive postoperative rehabilitation is a key for better functional outcomes. The limitation of our study is a smaller number of cases and short follow-up.

\section{CONCLUSION}

The functional outcome of dual plating for tibial plateau fractures is satisfying with minimal soft-tissue complications. The biomechanical stability provided with dual plate fixation helps functional outcome in the form of early rehabilitation to achieve full ROM. The postoperative complications can be reduced by proper timing of surgery, good soft tissue care intraoperatively and postoperatively. The overall functional and radiological outcomes at the end of 1 year are excellent to good in most of the cases which indicates that this technique is a good treatment option for type VI bicondylar tibial plateau fractures.

\section{Funding: No funding sources \\ Conflict of interest: None declared \\ Ethical approval: Not required}

\section{REFERENCES}

1. Li DQ, Song DY, Ni JD, Ding ML, Huang J. A case report of Schatzker type VI tibial plateau fracture treated with double reverse traction closed reduction combined with minimally invasive percutaneous plate osteosynthesis technique: A case report. Medicine. 2017;96:45.

2. Bhalotia AP, Ingle MV, Koichade MR. Necessity of dual plating in bicondylar tibial plateau fracture dislocations: A prospective case series. J Orthop Traumatol Rehabilitation. 2018;10(1):29.

3. Manjunath J, Ashish BC, Shashidhara H, Rao V. A prospective study of surgical management of bicondylar schatzker type V and VI tibial plateau fracture by dual plating and dual incision. Int $\mathrm{J}$ Orthop. 2019;5(3):46-54.

4. Rajappan DR, Ravikumar V, Suhail AP. Functional outcome of tibial plateau fractures, Schatzker type V and VI treated surgically with plate osteosynthesis. National J Clin Orthop. 2018;2(2):35-46.

5. Cho KY, Oh HS, Yoo JH, Kim DH, Cho YJ, Kim KI. Treatment of Schatzker type V and VI tibial plateau fractures using a midline longitudinal incision and dual plating. Knee surgery and related research. 2013;25(2):77.

6. Prasad GT, Kumar TS, Kumar RK, Murthy GK, Sundaram N. Functional outcome of Schatzker type V and VI tibial plateau fractures treated with dual plates. Indian j orthop. 2013;47:188-94.

7. Paleti ST, Kumar RN. Assessing the functional and Radiological outcome in surgically treated closed 
tibial plateau fractures in adults: A case series of 40 cases. Int J Orthop. 2019;5(1):472-6.

8. Marsh JL, Mattew Karam D. Tibial plateau fractures: chapter 55 Rockwood and Green fracture in adult's $8^{\text {th }}$ editon Wolters Kluwer health. 2015;2.

9. Barei DP, Sean Nork E, William Mills J, Chad Coles P, Bradford Henley M, Stephen Benirschke K. Functional Outcomes of Severe Bicondylar Tibial Plateau Fractures Treated with Dual Incisions and Medial and Lateral Plates. J Bone Joint Surg. 2006;88-a:8.
10. Mark Miller D. Review of orthopaedics. Basic Sci. 1992;1:42.

11. Rudloff MI. Fractures of the Lower Extremity, in Campbell's Operative Orthopaedics Elsevier. 2013;2668-724.

Cite this article as: Rao SKS, Mulla MAM, Malik $\mathrm{D}$, Usman M. Dual plate osteosynthesis in bicondylar tibial plateau fractures-case series. Int $\mathbf{J}$ Res Orthop 2021;7:848-53. 